\title{
CARACTERÍSTICAS GEOLÓGICAS E GEOTÉCNICAS DOS PRODUTOS DE ALTERAÇÃO DE GRANITOS E GNAISSES NOS ARREDORES DA CIDADE DE SÃO PAULO*
}

\author{
H.Godoy 1 \\ A.Carvalho ${ }^{2}$
}

O presente trabalho trata da caracterização geológica e geotécnica, para fins rodoviários, de produtos de alteração de granitos e gnaisses nos arredores da cidade de São Paulo.

Os estudos foram realizados em perfis de solo, com ênfase aos solos ditos saprolticos, que ao lado dos laterticos, constituem as duas grandes classes de solos, quanto ao seu comportamento geotécnico.

Foram estudados 5 perfis de alteração, sendo 2 em corpos graníticos (Itu e Itaqui) e 3 em gnaisses (Complexo Amparo), nos quais foram realizadas caracterizações macroscópicas, granulométricas, mineralógicas, micromorfológicas e geotécnicas.

Os perfis de alteração de granitos foram diferenciados dos de gnaisses pelas características macroscópicas, com exceção do perfil 5, que apresentava uma aparente isotropia, e que, no entanto, ao microscópio revelou tratar-se de material oriundo de gnaisse.

As caracterizações geológicas e geotécnicas realizadas nos materiais estudados permitiram, por um lado, a separação entre os níveis dos perfis (solum vs alterita) e mesmo entre perfis, e por outro lado, o estabelecimento de algumas correlações entre as diversas características.

Macroscopicamente, os niveis do solum apresentam menores espessuras, textura argilosa, tonalidades marrom-avermelhadas e estruturalmente são isótropos. As alteritas são mais espessas, com textura siltico-arenosa, as cores podem ser bege, róseo, entre outras, também havendo

\footnotetext{
*Apoio da FAPESP.

1Pós-graduação, Departamento de Geologia Geral, Instituto de Geociências, USP.

${ }^{2}$ Departamento de Geologia Geral, Instituto de Geociências e Núcleo de Pesquisa em Geoquímica e Geofisica da Litosfera, USP.
} 
mosqueamentos e manchas. As alteritas conservam, ao menos parcialmente, as estruturas litológicas e as texturas petrográficas da rocha de origem, proporcionando ao material, algumas vezes, uma forte anisotropia e heterogeneidade.

A granulometria do solum diferencia-se da alterita por apresentar um enriquecimento da fração argila.

O elenco mineralógico do solum é basicamente o mesmo das alteritas, apresentando, entretanto, uma quantidade substancialmente maior de minerais secundários.

Os resultados dos ensaios geotécnicos não mostraram com a mesma clareza a diferenciação entre os niveis do solum e o das alteritas. Assim as deformações que são realçadas nas curvas de compactação, aparecem com menor evidência nos resultados de Perda de Massa por Imersão (Pi) e Expansão e não são identificáveis pelos valores de M-CBR.

Entre os perfis ocorrem semelhanças de características que permite separá-los em dois grandes grupos.

O grupo 1 é composto dos perfis 1 e 5 , e o grupo 2 dos perfis 2,3 e 4 .

No grupo 1, a classe granulométrica menor que $2 \mathrm{~mm}$ predominante é a da areia, com cerca de $70 \%$, enquanto a razão silte/argila está por volta de 3 . Já, no grupo 2 , ocorre preponderância da fração silte e a razão silte/argila varia de 1 a 10.

O elenco mineralógico do grupo 1 está composto de quartzo, feldspatos, micas, goethita e gibbsita. 0 grupo 2 difere do 1 pela ausência de feldspatos e uma maior quantidade de minerais secundários.

Os resultados dos ensaios M-MCV, Pi e expansão corroboram com a divisão em grupos. Assim, as densidades alcançadas pelos níveis são maiores no grupo 1, os valores de $\mathrm{Pi}$ apresentam-se entre 80 e $271 \%$, enquanto no grupo 2 os valores podem ser nulos ou variar até o extremo de 300\%; a Expansão apresenta valores menores para o grupo 1 do que para o 2. Por outro lado, os valores de M-CBR, por estarem muito dispersos, não contribuíram com a separação em grupos.

Esta divisão em grupos é decorrência da atuação diferenciada da alteração, que por sua vez, tem como principal condicionante o grau de deformação (fraturamento) sofrido pelas rochas.

Quanto às relações entre as diversas características observa-se que a maior quantidade de minerais primários (quartzo + feldspatos) refletem numa granulometria mais grosseira; em materiais com densidades maiores na compactação; em menor faixa de variação da Pi e menores valores de expansão. 
Por outro lado, correlações mais estreitas tornam-se difíceis de serem estabelecidas, pois, atualmente, existem obstáculos na determinação da quantidade, tamanho e forma dos minerais ou de seus agregados.

Finalmente, os resultados obtidos mostram que estudos da organização (estrutura) dos materiais podem ser muito úteis para fornecer respostas para muitos dos problemas de correlações, uma vez que é atribuida à estruturação do solo boa parte da resistência a esforços que esse material pode suportar. 